\title{
Sagitta otolith of three demersal species in a tropical environment
}

\author{
Crismen Santana de Oliveira ${ }^{1,4}$; Kátia de Meirelles Felizola Freire ${ }^{1,5}$; Leonardo Cruz da Rosa ${ }^{2,6}$ \& Barbara Maichak de Carvalho ${ }^{3,7}$ \\ ${ }^{1}$ Universidade Federal de Sergipe (UFS), Centro de Ciências Agrárias Aplicadas (CCAA), Departamento de Engenharia de Pesca e Aquicultura (DEPAQ), \\ Laboratório de Ecologia Pesqueira. São Cristóvão, SE, Brasil. \\ 2 Universidade Federal de Sergipe (UFS), Centro de Ciências Agrárias Aplicadas (CCAA), Departamento de Engenharia de Pesca e Aquicultura (DEPAQ), \\ Laboratório de Ecologia Bentônica. São Cristóvão, SE, Brasil. \\ 3 Universidade Federal do Paraná (UFPR), Setor de Ciências da Terra, Departamento de Engenharia Ambiental (DEA), \\ Laboratório de Ecologia e Conservação (LEC), Programa de Pós-Graduação em Engenharia Ambiental. Pontal do Paraná, PR, Brasil. \\ ${ }^{4}$ ORCID: http://orcid.org/0000-0003-4891-3485. E-mail: crismensoliv@gmail.com \\ ${ }^{5}$ ORCID: http://orcid.org/0000-0002-6190-3532.E-mail: kmffreire2018@gmail.com \\ ${ }^{6}$ ORCID: http://orcid.org/0000-0002-4263-332X. E-mail: leonardo.rosa@rocketmail.com \\ ${ }^{7}$ ORCID: http://orcid.org/0000-0001-7958-427X. E-mail: bmaicarvalho@gmail.com (corresponding author)
}

\begin{abstract}
The objective of this study was to describe the morphology and morphometry of saggitta otoliths of Polydactylus virginicus, Menticirrhus cuiaranensis and Conodon nobilis in a tropical environment. Fishes were caught with rod and reel in competitive fishing events promoted in 2014-2015 along the coast of Sergipe. A total of 174 pairs of sagitta otoliths of P. virginicus, 181 of $M$. cuiaranensis and 77 of C. nobilis was extracted. In general, the sagitta otoliths of all three species analyzed here presented different morphology and shape indices. The permutational multivariate analysis of variance (PERMANOVA) demonstrated significant differences among species and ontogenetic phases within each species using morphometry and shape indices. The linear discriminant analysis (LDA) presented a $98.3 \%$ correct reclassification of the otoliths by species.
\end{abstract}

Keywords. Conodon nobilis; Menticirrhus cuiaranensis; Polydactylus virginicus; Ontogenetic variation; Shape indices.

\section{INTRODUCTION}

Otoliths are calcium carbonate precipitated primarily as aragonite structures, present in the inner ear of fishes in three pairs: sagittae, asterisci and lapilli (Popper et al., 2005). They are metabolically inert, i.e., there is no chemical alteration or reabsorption after their formation. These structures assist the hearing and perception of the external environment (Ladich \& Schulz-Mirbach, 2016). Otoliths are excellent tools for various studies of fish populations such as: habitat use and connectivity between populations using the chemistry of the otolith (Carvalho et al., 2017; Maciel et al., 2020), environmental stress indicated by the deposition of vaterita (Carvalho et al., 2019a; Holmberg et al., 2019), and age and growth (Soeth et al., 2018; Maciel et al., 2018).

Many studies correlate the ontogenetic developments of otoliths to life history and changes in habitat use as distribution in the water column (Cruz \& Lombarte, 2004; Assis et al., 2020). Taylor et al. (2020) correlated changes in the morphology and morphometry of the otoliths of Argyrosomus japonicus with the segregation of habitat use of juveniles and adults. The morphology and morphometry of otoliths may present sexual variation, as observed in Atherinella brasiliensis (Quoy \& Gaimard, 1825), Micromesistius australis (Norman, 1937) and Porichthys notatus (Girard, 1854) (Carvalho \& Correa, 2014; Leguá et al., 2013; Bose et al., 2016), as well as before and after the first maturity within the same species (Carvalho et al., 2020). The intraspecific morphologies and morphometric patterns of otoliths make them an important tool for studies of trophic ecology of ichthyophagous species (Miotto et al., 2017; Carvalho et al., 2019b). Some of the species identified as preys are also exploited in artisanal and recreational fisheries (Cattani et al., 2011; Freire et al., 2017; Passarone et al., 2019). Polydactylus virginicus (Linnaeus, 1758), Menticirrhus cuiaranensis (Marceniuk et al., 2020) and Conodon nobilis (Linnaeus, 1758) are examples of species exploited by recreational fishers (Freire et al., 2017) and are usually described as food items in the diet of ichthyophagous species (Tavares \& Di Beneditto, 2017). Those species are demersal and distributed in the Southwestern Atlantic Ocean (Menezes \& Figueiredo, 1980; Froese \& Pauly, 2021). 
Menticirrhus cuiaranensis and C. nobilis are benthophagous (Lira et al., 2019) whereas $P$. virginicus is zooplanktivore (Medeiros et al., 2017).

Several studies have described the morphology and morphometry of otoliths of species important for artisanal and recreational fisheries in southeastern-southern Brazil (Siliprandi et al., 2014; Brenha-Nunes et al., 2016; Maciel et al., 2019; Dal Negro et al., 2021). Conversely, few studies have been conducted in northeastern Brazil, making it impossible future studies of connectivity or fishing stocks for species with wide distribution along the Brazilian coast (Freire et al., 2017; Assis et al., 2020; Bot et al., 2020). Thus, this study was conducted with the objective of describing the morphology and morphometry of sagitta otoliths of $P$. virginicus, $M$. cuiaranensis and $C$. nobilis, and assessing the occurrence of ontogenetic changes to serve as basis for future studies related to diet composition and connectivity between populations.

\section{MATERIAL AND METHODS}

Samplings were performed between March 2014 and August 2015 in distinct beaches along the coast of the state of Sergipe, in northeastern Brazil (Fig. 1). Recreational fishers used rod, reel, and hook with natural bait during these events (Freire et al., 2017). The specimens caught were identified, measured for total length and total weight ( $T L$, in centimeters and $\mathrm{W}$, in grams, respectively). Power relations were also estimated between total length and total weight $\left(W=a \cdot T L^{b}\right)$ (positive allometry, $\mathrm{b}>3$; negative allometry, $\mathrm{b}<3$; and isometry, $b=3$; Froese, 2006). The specimens were separated into six length classes (5.1-10; 10.1-15; 15.1-20; 20.1-25; 25.1-30; 30.1-35 cm) to test for ontogenetic variation. Sagitta otoliths were washed, dried, and stored separately in small paper envelopes. Voucher specimens are deposited in the collection of the "Acervo Zoológico da Universidade Santa Cecília" under the numbers AZUSCUNISANTA n. 5155, 5169, and 5935.

\section{Morphology and morphometry of otolith}

The identification of otolith shape, position, type and shape of the sulcus acusticus, shape of the cauda, and ostium type was performed according to Corrêa \& Vianna
(1992), Tuset et al. (2008), and Volpedo \& Vaz-dos-Santos (2015). The otolith length (OL, greater longitudinal distance in $\mathrm{mm})$ and height $(\mathrm{OH}$, greater perpendicular distance in $\mathrm{mm}$ ) were measured (Fig. 2). Power relations were also estimated between otolith length (OL) and height $(\mathrm{OH})$ and fish total length $(\mathrm{TL}): \mathrm{OL}=\mathrm{a} \cdot \mathrm{TL}^{\mathrm{b}}$ and $\mathrm{OH}=\mathrm{a} \cdot \mathrm{TL}^{\mathrm{b}}$. The following otolith shape indices were used to verify the ontogenetic variation as well as variation among species: OL/TL, OH/OL × 100 (Volpedo \& Echeverria, 2003), and ellipticity $[\mathrm{E}=(\mathrm{OL}-\mathrm{OH}) /(\mathrm{OL}+\mathrm{OH})]$ (Tuset et al., 2003).

\section{Statistical analysis}

The morphometry and shape indices did not meet the assumptions required for parametric tests in all three species analyzed here (Shapiro-Wilk: $p<0.05$; Bartlett's test: $p<0.05)$. Hence, a Permutational Analysis of Variance (PERMANOVA) was applied to verify ontogenetic differences within species and shape variation among species using the morphometry and shape indices for all three species. A linear discriminant analysis (LDA) was performed to verify the percentage of correct

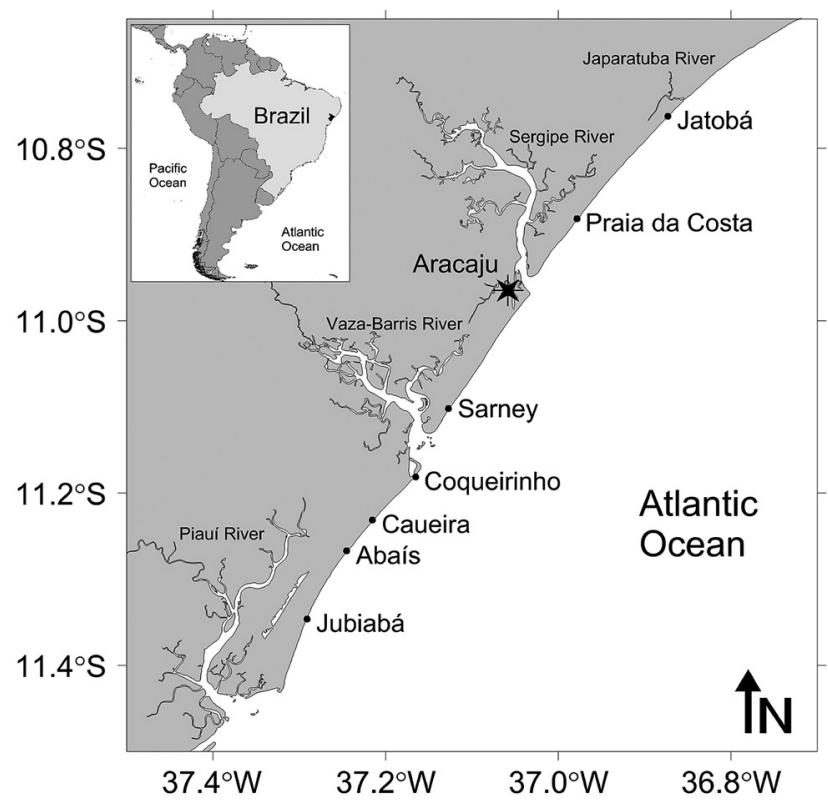

Figure 1. Map of the coastal region of the state of Sergipe showing all the beaches where samples were collected during competitive fishing events in 2014-2015.

\section{A) Height}

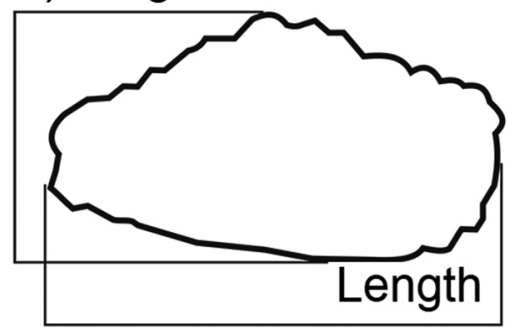

B) Height

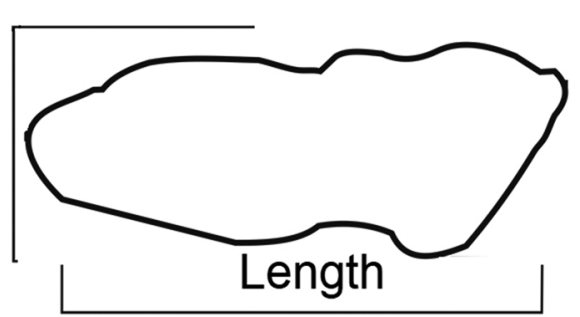

C) Height

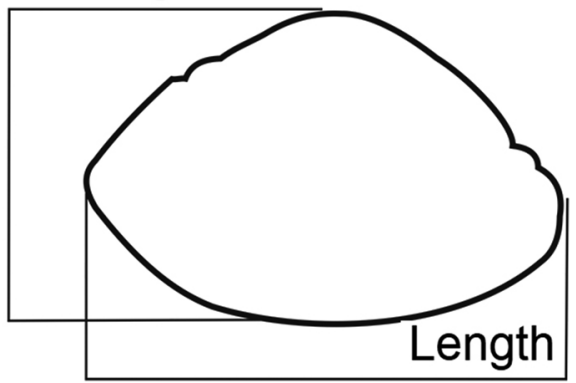

Figure 2. Length and height of sagittae otoliths for: (A) Polydactylus virginicus; (B) Menticirrhus cuiaranensis; and (C) Conodon nobilis. 
reclassification of otoliths among the three species analyzed (Linde et al., 2004). All statistical analyses were performed using the R software (R Core Team, 2020) and Past (Hammer et al., 2001).

\section{RESULTS}

A total of 487 individuals of $P$. virginicus ( $T L=7.2$ to $27.5 \mathrm{~cm} ; \mathrm{n}=229$ ), M. cuiaranensis ( $\mathrm{TL}=12.5$ to $35.5 \mathrm{~cm}$; $\mathrm{n}=182$ ), and C. nobilis ( $\mathrm{TL}=7.4$ to $33.5 \mathrm{~cm}, \mathrm{n}=76$ ) were analyzed (Fig. 3). The morphological analysis of the otoliths indicated interspecific variation (Table 1), except for the shape of the sulcus acusticus and cauda, which are similar for all three species. The position and type of the sulcus acusticus are similar for $P$. virginicus and $C$. nobilis,
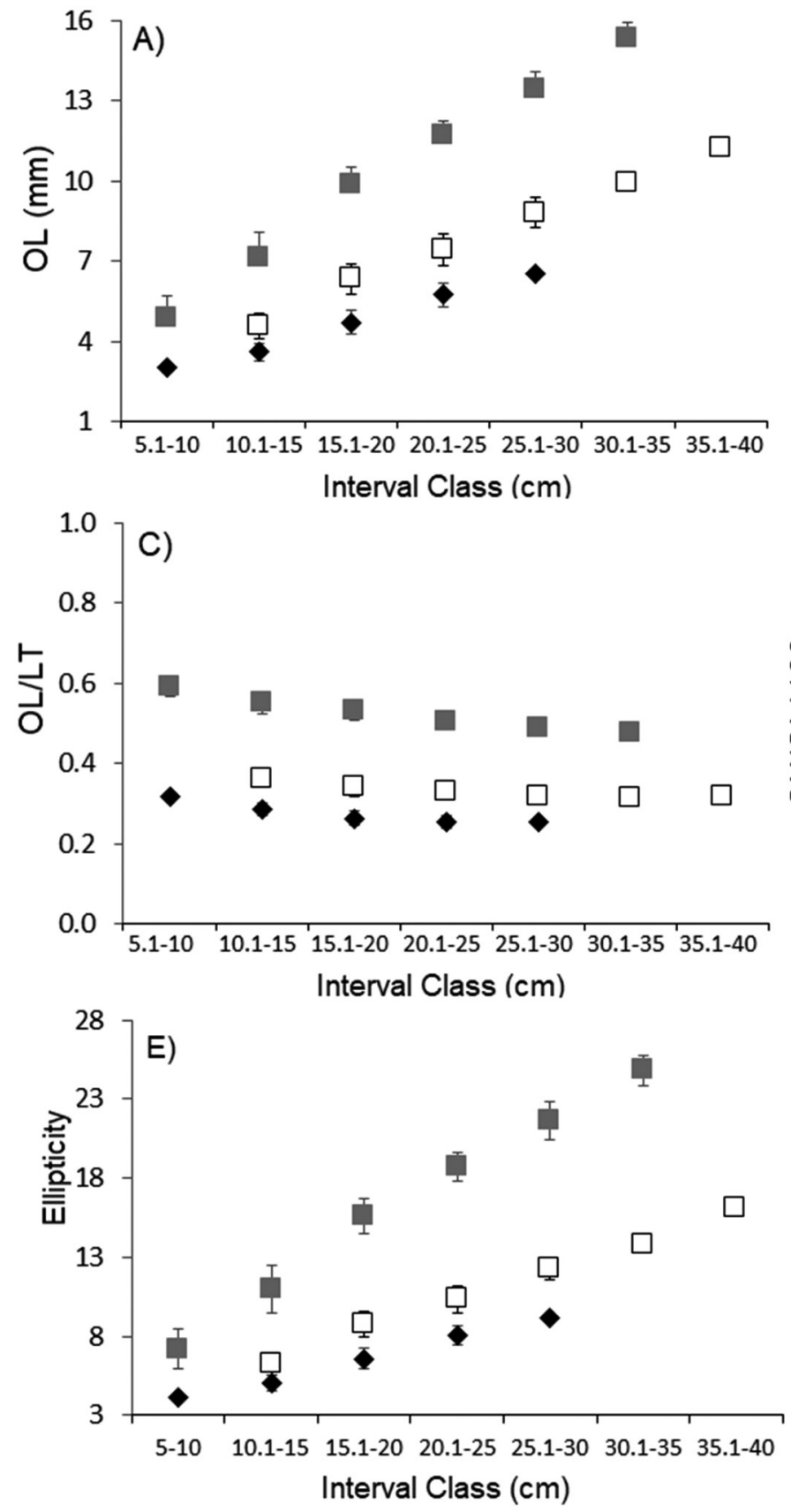

i.e., median and ostial. Menticirrhus cuiaranensis showed on rostrum and $P$. virginicus and $C$. nobilis showed a small and underdeveloped rostrum.

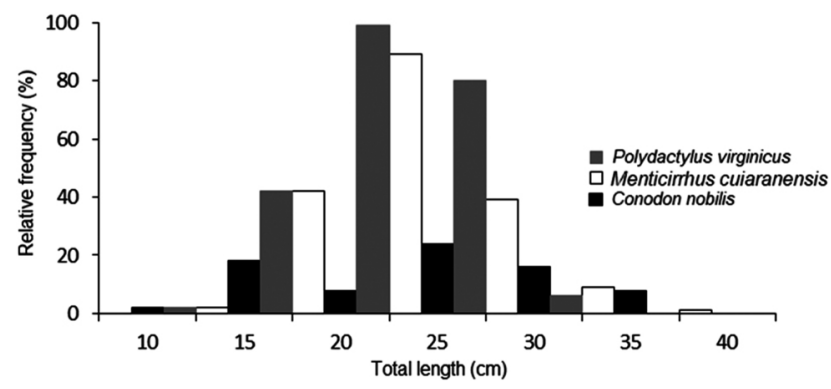

Figure 3. Frequency distribution of the total length $(\mathrm{cm})$ of Polydactylus virginicus, Menticirrhus cuiaranensis and Conodon nobilis sampled in a tropical environment in Southwestern Atlantic.
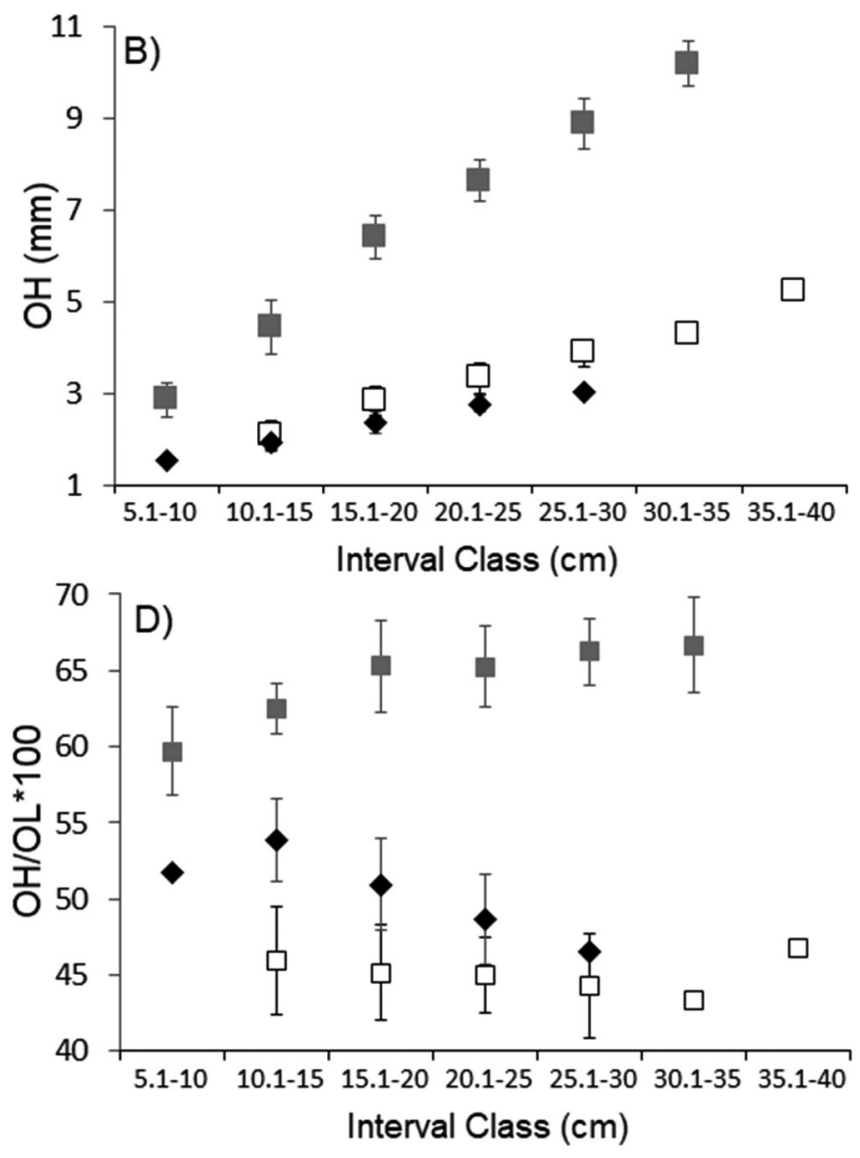

Polydactylus virginicus

$\square$ Menticirrhus cuiaranensis

$\square$ Conodon nobilis

Figure 4. Box plot (mean and standard deviation) of morphometric parameters and shape indices of the otolith sagitta of Polydactylus virginicus, Menticirrhus cuiaranensis and Conodon nobilis per class of total length: (A) otolith length (OL), (B) otolith height (OH), (C) Aspect ratio OL/TL, (D) Aspect ratio (OH/OL) $\times 100$ and (E) ellipticity. 
Morphometry and indices demonstrated ontogenetic variation within the three species analyzed here (Fig. 4). The otoliths of $C$. nobilis tend to be more rounded along the ontogeny and the otoliths of $M$. cuiaranensis and $P$. virginicus tend to be more elongated as the ontogenetic development occurs (Fig. 4D). The otoliths of the three species show greater growth in the anteroposterior axis along the ontogeny (Fig. 4E). The results of the PERMANOVA $(F=807.1 ; p<0.0001)$ indicated significant differences in the morphometry of otolith and shape indices among species.

Both $P$. virginicus and $M$. cuiaranensis presented positive body allometry when analyzing the weight-length relationship ( $b=3.233$ and 3.159, respectively; Fig. 5). On the other hand, C. nobilis showed body isometry $(b=3.022)$, with an increase in its body weight proportional to the cube of its length. At the same time, C. nobilis was the only species, among all analyzed, with otoliths presenting a strong positive allometry $(b=3.744$; Fig. 5$)$.

The LDA showed a variation in the shape of the sagitta otoliths: $M$. cuiaranensis presents otoliths distributed along axis 1 for presenting more elongated otoliths; and $P$. virginicus and $C$. nobilis are distributed along axis 2 , which better explains the variability of the more rounded otoliths (Fig. 6). The LDA presented a 98.3\% correct reclassification of the otoliths by species (Table 2 ).
Table 1. Morphological classification of otoliths for Polydactylus virginicus, Menticirrhus cuiaranensis and Conodon nobilis of a tropical environment.

\begin{tabular}{llll}
\hline \multicolumn{1}{c}{ Morphological features } & \multicolumn{1}{c}{ P. virginicus } & \multicolumn{1}{c}{ M. cuiaranensis } & \multicolumn{1}{c}{ C. nobilis } \\
\hline Rostrum & Small & Absent & Developed \\
Shape of otolith & Rectangular & Bullet shaped & Oval \\
Position of sulcus acusticus & Median & Inframedian & Median \\
Type of sulcus acusticus & Ostial & Pseudo-ostial & Ostial \\
Shape of sulcus acusticus & Heterosulcoid & Heterosulcoid & Heterosulcoid \\
Shape of cauda & Curved & Curved & Curved \\
Type of ostium & Funnel & Lateral & Rectangular \\
\hline
\end{tabular}

Table 2. Reclassification of the sagitta otoliths for Polydactylus virginicus, Menticirrhus cuiaranensis and Conodon nobilis obtained through the linear discriminant analysis (LDA).

\begin{tabular}{lccc}
\hline \multicolumn{1}{c}{ Species } & M. cuiaranensis & C. nobilis & P. virginicus \\
\hline P. virginicus & $0(0)$ & $0(0)$ & $156(100)$ \\
M. cuiaranensis & $171(97.1)$ & $0(0)$ & $5(2.9)$ \\
C.nobilis & $0(0)$ & $72(94.7)$ & $4(5.3)$ \\
\hline Total & 171 & 72 & 165 \\
\hline
\end{tabular}

\section{DISCUSSION}

In general, the sagitta otoliths of all three species analyzed here presented different morphology. However,
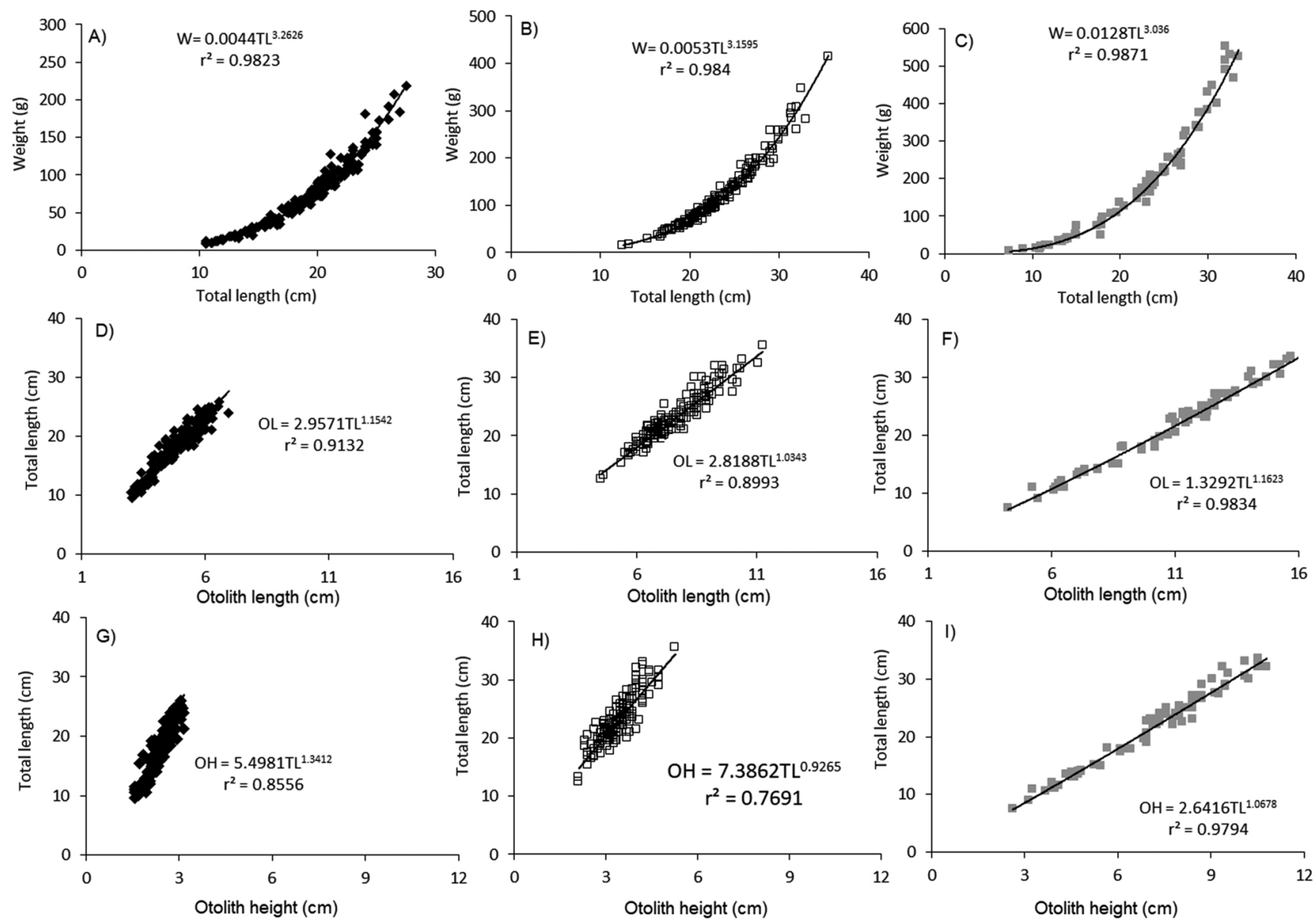

Figure 5. Length-weight relationship for (A) Polydactylus virginicus, (B) Menticirrhus cuiaranensis, and (C) Conodon nobilis; otolith length vs fish total length for (D) Polydactylus virginicus, (E) Menticirrhus cuiaranensis, and (F) Conodon nobilis; and otolith height vs fish total length for (G) Polydactylus virginicus, (H) Menticirrhus cuiaranensis, and (I) Conodon nobilis. 


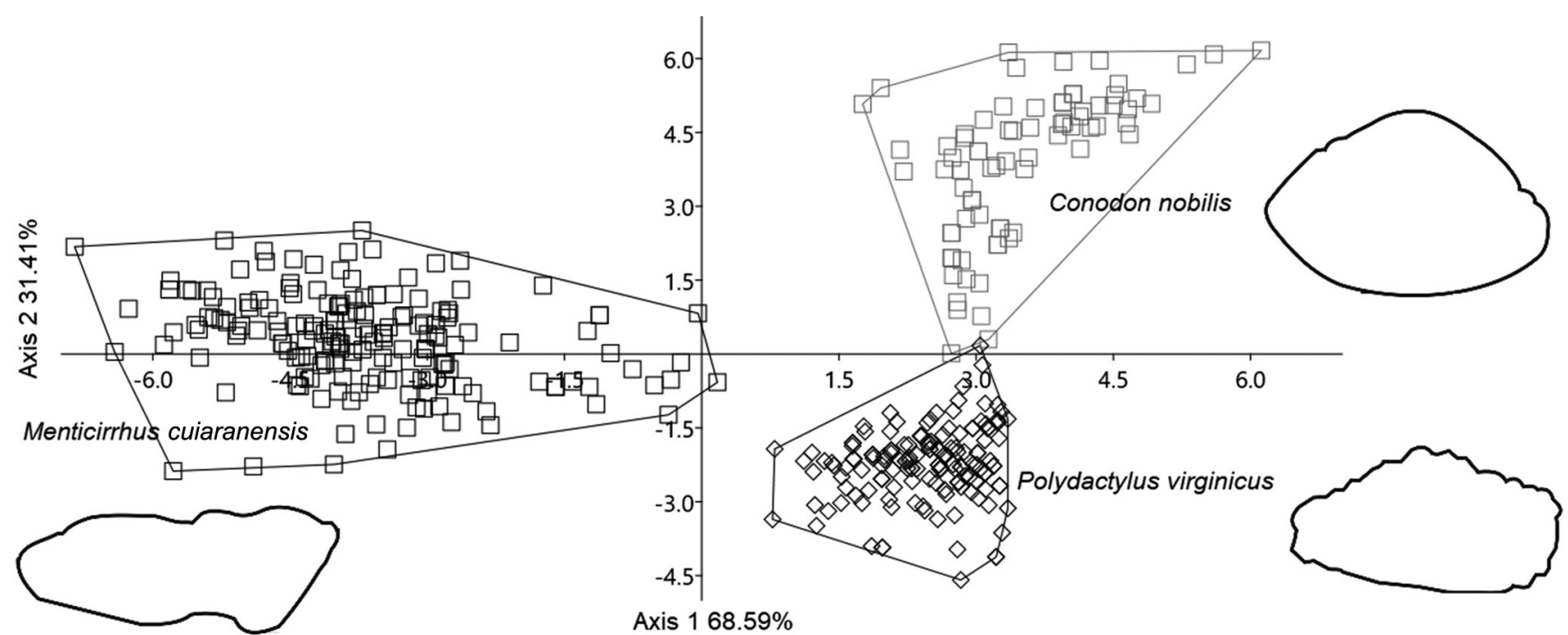

Figure 6. Scatterplot of the linear discriminant analysis of morphometry and shape indices of the sagitta otolith of Polydactylus virginicus, Menticirrhus cuiaranensis and Conodon nobilis.

similarities were observed in the shape of the sulcus acusticus and cauda for all of them, and also in the position and type of sulcus acusticus for P. virginicus and C. nobilis. Even though P. virginicus, M. cuiaranensis and C. nobilis are demersal species, the otolith shape is different among them (rectangular, bullet shaped, and oval, respectively). For Gauldie (1988), it is the shape of the sulcus, and not the otolith shape, that is associated with acoustic sensitivity, which in turn depends on the habitat. However, this author did not present details on how this association works. In the present study, the shape of the sulcus acusticus was heterosulcoid for all three demersal species analyzed. The exact mechanism that relates the sulcus shape with higher acoustic sensitivity would have to be better investigated in future studies. Additionally, Cruz \& Lombarte (2004) pointed out that Sciaenidae and Haemulidae families, which include $M$. cuiaranensis and C. nobilis, respectively, belong to groups specialized in sound production. This could be associated with relatively large otoliths for better acoustic communication.

Our study was the first to evaluate the ontogenetic variation of otoliths for $P$. virginicus, $M$. cuiaranensis and C. nobilis using shape indices. Only the $\mathrm{OH} / \mathrm{OL} \times 100 \%$ demonstrated a change in trend associated with ontogenetic variation mainly for $P$. virginicus and $C$. nobilis. According to Volpedo \& Echeverria (2003), values of aspect ratio between $21 \%$ and $96 \%$ and the absence of rostrum indicate species associated with a soft bottom. Conversely, species associated with a consolidated substrate show values between $41 \%$ and $67 \%$ and a small rostrum. The aspect ratio and the presence of a small rostrum indicate that $P$. virginicus and $C$. nobilis inhabit consolidated and soft substrates, respectively (BrenhaNunes et al., 2016; Santificetur et al., 2017). The absence of rostrum indicates that $M$. cuiaranensis lives in environments of unconsolidated sediment as mentioned for other species of the same genus Menticirrhus (Carvalho et al., 2020). Polydactylus virginicus showed a reduction in the aspect ratio in specimens larger than $15 \mathrm{~cm} \mathrm{TL}$, when this species starts the maturation process (Freire et al.,
2020). This may indicate a change in habitat after maturity between juveniles and adults, or in swimming capacity associated with feeding change. On the other hand, the aspect ratio of the otoliths from $C$. nobilis increased until specimens were $20 \mathrm{~cm}$ TL long and kept stable onwards. Note that the length at first maturity for this species is about $21 \mathrm{~cm}$ TL in a neighboring area (da Silva et al., 2019). Here, again, a change in habitat for juveniles and adults may be occurring. The otoliths of Menticirrhus are elongated (Siliprandi et al., 2014; Carvalho et al., 2020), as also observed for $M$. cuiaranensis in the present study, but no change was observed in the aspect ratio for the length range analyzed here.

According to lizuka \& Katayama (2008), demersal species present otoliths within two groups defined by their external shape: elongate (or elliptical) and orbicular (or ellipsoidal). This difference was evident for the three species analyzed here, with elliptical otoliths found in $P$. virginicus and $M$. cuiaranensis, and ellipsoidal in C. nobilis. Moreover, the former two species presented a positive allometry in the relationship between body weight and length, but negative when the same relationship was estimated for the otolith. On the other hand, $C$. nobilis presented body isometry, but a positive otolith allometry, which is related to the ellipsoidal shape of its sagitta otolith. Hence, otoliths of $C$. nobilis are disproportionately heavier than the other two species. One could hypothesize that $C$. nobilis presents higher acoustic sensitivity based on Lychakov \& Rebane (2000), who stated that the heavier the otolith, the higher its acoustic sensitivity in lower frequency. This higher acoustic sensitivity should be further investigated in future studies involving C. nobilis.

The otolith shape is usually species-specific, but intraspecific geographic variation may occur due to environmental factors (Santos et al., 2017; Maciel et al., 2020). The morphology and morphometry of the otoliths from $P$. virginicus and $C$. nobilis were analyzed in previous studies carried on southeastern-southern Brazil (Brenha-Nunes et al., 2016; Santificetur et al., 2017), showing similar char- 
acteristics to specimens inhabiting northeastern Brazil. The applied methodology was not the most sensitive to determine contour variations that may show latitudinal influence. Several external factors can influence the otolith shape (Torres et al., 2000; Capoccioni et al., 2011; Avigliano et al., 2012), including beach hydrodynamics. However, no study has been conducted in Brazil correlating these two variables. Could the differences observed in the otoliths of the three species represent a response to the beach dynamics? Future studies of the morphology and morphometry of the otoliths of such demersal coastal species should try to correlate the beach hydrodynamics with the otolith shape.

\section{ACKNOWLEDGMENTS}

All authors would like to thank the Universidade Federal de Sergipe for the scholarship provided to the first author (COPES/UFS), to all recreational fishers from the Associação Sergipana de Pesca Amadora Bons Ventos (ASPA-BV) for donating their catch from fishing competitive events to be analyzed in this study, to Rodrigo Melins, Rafael Barbosa, Ana Cláudia dos Santos, and Osmir Fabiano for helping with sample processing, and to Daniel Assis and Roberto Schwarz for their comments on an earlier version of this manuscript. B.M.C. is thankful to the National Council for Scientific and Technological Development (CNPq 153090/2019-7).

\section{AUTHORS' CONTRIBUTIONS}

C.S.O.: Collection, data collection, data analysis and writing. K.M.F.F.: Collection, data collection, data analysis and writing. L.C.R.: Discussion of data and assistance in the preparation of the final version of the manuscript. B.M.C.: Data analysis and writing.

\section{REFERENCES}

Assis, I.0.; Silva, V.E.L; Souto-Vieira, D.; Lozano, A.P.; Volpedo, A.V. \& Fabré, N.N. 2020. Ecomorphological patterns in otoliths of tropical fishes: assessing trophic groups and depth strata preference by shape. Environmental Biology of Fishes, 103: 349-361. DOI

Avigliano, E.; Tombari, A. \& Volpedo A.V. 2012. ¿El otolito de pejerrey (Odontesthes bonariensis), refleja el estrés ambiental? Biología Acuática, 27: 9-15.

Bose, A.P.H.; Adragna, J.B. \& Balshine, S. 2016. Otolith morphology varies between populations, sexes and male alternative reproductive tactics in a vocal toadfish Porichthys notatus. Journal of Fish Biology, 90(1): 1-15. DOI

Bot, R.L.N.; Carvalho, B.M.; Schwarz-Júnior, R. \& Spach, H.L. 2020. Ontogenetic variation in the sagitta otolith of Centropomus undecimalis (Actinopterygii: Perciformes: (entropomidae) in a tropical estuary. Acta Ichthyologica et Piscatoria, 50(4): 433-443. DOI

Brenha-Nunes, M.R.; Santificetur, C.; Conversani, V.R.M.; Giaretta, M.B.; Rossi-Wongtschowski C.L.D.B. \& Siliprandi C.C. 2016. Atlas of marine bony fish otoliths (sagittae) of southeastern-southern Brazil.
Part IV: Perciformes (Centropomidae, Acropomatidae, Serranidae, Priacanthidae, Malacanthidae, Pomatomidae, Carangidae, Lutjanidae, Gerreidae and Haemulidae). Brazilian Journal of Oceanography, 64 (spec. 1): 23-75. DOI

Capoccioni, F.; Costa, C.; Aguzzi, J.; Menesatti, P.; Lombarte, A. \& Ciccotti, E. 2011. Ontogenetic and environmental effects on otolith shape variability in three Mediterranean European eel (Anguilla anguilla, L.) local stocks. Journal of Experimental Marine Biology and Ecology, 397(1): 1-7.

Carvalho, B.M. \& Corrêa, M.F.M. 2014. Morphometry of the sagitta otolith from Atherinella brasiliensis (Quoy and Gaimard, 1824) (Actinopterygii - Atherinopsidae), at the coast of Paraná. Tropical Oceanography, 42: 54-59.

Carvalho, B.M.; Volpedo, A.V.; Albuquerque, C.Q. \& Fávaro LF. 2019a. First record of anomalous otoliths of Menticirrhus americanus in the South Atlantic. Journal of Applied Ichthyology, 35: 1286-1291. D01

Carvalho, B.M.; Spach, H.L.; Vaz-dos-Santos, A.M. \& Volpedo, A.V. $2019 \mathrm{~b}$. Otolith shape index: Is it a tool for trophic ecology studies? Journal of the Marine Biological Association of the United Kingdom, 99(7): 1675-1682. DOI

Carvalho, B.M.; Volpedo, A.V. \& Fávaro, L.F. 2020. Ontogenetic and sexual variation in the sagitta otolith of Menticirrhus americanus (Teleostei; Sciaenidae) (Linnaeus, 1758) in a subtropical environment. Papéis Avulsos de Zoologia, 60: 1-12. D0I

Carvalho, B.M.; Volpedo, A.V.; Vaz-dos-Santos, A.M. \& Spach, H.L. 2017. Use of otolith microchemistry as an indicator of the habitat of Anchoa tricolor (Spix \& Agassiz, 1829) in a subtropical estuary. Latin American Journal of Aquatic Research, 45: 457-465. DOI

Cattani, A.P.; Santos, L.0.; Spach, H.L.; Budel, B.R. \& Gondim Guanais, J.H.D. 2011. Avaliação da ictiofauna da fauna acompanhante da pesca do camarão sete-barbas do município de Pontal do Paraná, litoral do Paraná, Brasil. Boletim do Instituto Pesca, 37: 247-260.

Corrêa, M.F.M. \& Viana, M.S. 1992. Catálogo dos otólitos sagitta de Sciaenidae (Osteichthyes - Perciformes) do litoral do estado do Paraná, Brasil. Nerítica, 7: 13-41.

Cruz, A. \& Lombarte, A. 2004. Otolith size and its relationship with colour patterns and sound production. Journal of Fish Biology, 65: 1512-1525. D0I

Dal Negro, T.; Santos, P.P.; Tutui, S.L.S. \& Tomás, A.R.G. 2021. Coastal recreational fisheries: A case study in the southeastern Brazil. Regional Studies in Marine Science, 42: 101652. D0I

Freire, K.M.F.; Nascimento, F.P. \& Rocha, G.R.A. 2020. Shore-based competitive recreational fisheries in southern Bahia, Brazil: A baseline study. Marine and Fishery Sciences, 33: 183-203. D01

Freire, K.M.F.; Oliveira, C.S. \& da Rosa, L.C. 2017. Morphometric analysis of otoliths of juvenile crucifix sea catfish Sciades proops (Valenciennes, 1840). Journal of Applied Ichthyology, 485-490. D0I

Froese, R. \& Pauly, D. 2021. FishBase. World Wide Web electronic publication. www.fishbase.org, version (01/2021).

Gauldie, R.W. 1988. Function, form and time-keeping properties of fish otoliths. Comparative Biochemistry and Physiology - Parte A: Molecular \& Integrative Physiology, 91(2): 395-402.

Hammer, Ø.; Harper, D.A.T. \& Ryan, P.D. 2001. Past: Paleontological Statistics Software Package for Education and Data Analysis. Palaeontologia Electronica, 4: 1-9.

Holmberg, R.J.; Wilcox-Freeburg, E.; Rhyne, A.L.; Tlusty, M.F.; Stebbins, A.; Nye, S.W.; Honig, A.; Johnston, A.E.; San Antonio, C.M.; Bourque, B. \& Hannigan, R.E. 2019. Ocean acidification alters morphology of all otolith types in Clark's anemonefish (Amphiprion clarkii). PeerJ, 7: 1-24. D01

lizuka, K. \& Katayama, S. 2008. Otolith morphology of teleost fishes of Japan. Bulletin of Fisheries Research Agency, 25: 1-222. 
Ladich, F. \& Schulz-Mirbach, T. 2016. Diversity in Fish Auditory Systems: One of the Riddles of Sensory Biology. Frontiers in Ecology and Evolution, 4: 1-27. DOI

Leguá, J.; Plaza, G.; Pérez, D. \& Arkhiphin, A. 2013. Otolith shape analysis as a tool for stock identification of the southern blue whiting, Micromesistius australis. Latin American Journal of Aquatic Research, 41(3): 479-489. D0l

Linde, M.; Palmer, M. \& Gomez-Zurita, J. 2004. Differential correlates of diet and phylogeny on the shape of the premaxilla and anterior tooth in sparid fishes (Perciformes: Sparidae). Journal of Evolutionary Biology, 17: 941-952. DOI

Lira, A.S.; Viana, A.P.; Eduardo, L.N.; Lucena-Fredóu, F. \& Frédou, T. 2019. Population structure, size at first sexual maturity, and feeding ecology of Conodon nobilis (Actinopterygii: Perciformes: Haemulidae) from the coasts of Pernambuco, north-eastern Brazil. Acta Ichthyologica et Piscatoria, 49(4): 389-398. DOI

Lychakov, D.V. \& Rebane, Y.T. 2000. Otolith regularities. Hearing Research, 143(1-2): 83-102. DOI

Maciel, T.R.; Avigliano, E.; Carvalho, B.M.; Miller, N. \& Vianna, M. 2020. Population structure and habitat connectivity of Genidens genidens (Siluriformes) in tropical and subtropical coasts from Southwestern Atlantic. Estuarine, Coastal and Shelf Science, 242: 1-11. D01

Maciel, T.R.; Vaz-dos-Santos, A.M. \& Vianna, M. 2018. Can otoliths of Genidens genidens (Cuvier 1829) (Siluriformes: Ariidae) reveal differences in life strategies of males and females? Environmental Biology of Fishes, 201: 1589-1598. D0l

Maciel, T.R.; Vaz-dos-Santos, A.M.; Barradas, J.R.D.S. \& Vianna M. 2019. Sexual dimorphism in the catfish Genidens genidens (Siluriformes: Ariidae) based on otolith morphometry and relative growth. Neotropical Ichthyology, 17(1): 1-8. DOI

Marceniuk, A.P.; Caires, R.A.; Rotundo, M.M.; Cerqueira, N.N.C.D.; SicchaRamirez, R.; Wosiacki, W.B. \& Oliveira, C. 2020. Taxonomic revision of the Menticirrhus americanus (Linnaeus, 1758) and M. littoralis (Holbrook, 1847) (Percomorphacea: Sciaenidae) species complexes from the western Atlantic. Zootaxa, 4822(3): 301-333.

Medeiros, A.P.M.; Xavier, J.H.A. \& Rosa, I.M.L. 2017. Diet and trophic organization of the fish assemblage from the Mamanguape River Estuary, Brazil. Latin American Journal of Aquatic Research, 45(5): 879-890. D0I

Menezes, N.A. \& Figueiredo, J.L. 1980. Manual de peixe marinhos do sudeste do Brasil Teleostei I. São Paulo, Museu de Zoologia, Universidade de São Paulo. v. 3, p. 42-59.

Miotto, M.; Carvalho, B.M. \& Spach, H.L. 2017. Does the closed fishing season influence the ichthyofauna consumed by Larus dominicanus? Brazilian Journal of Oceanography, 65: 9-18. D0l

Passarone, R.; Aparecido, K.C.; Eduardo, L.N.; Lira, A.S.; Silva, L.V.S.; Justino, A.K.S.; Craveiro, C.; Silva, E.F. \& Frédou, F.L. 2019. Ecological and conservation aspects of bycatch fishes: An evaluation of shrimp fisheries impacts in Northeastern Brazil. Brazilian Journal of Oceanography, 67: 1-11. D0I

Popper, A.N.; Ramcharitar, J. \& Campana S.E. 2005. Why otoliths? Insights from inner ear physiology and fisheries biology. Marine and Freshwater Research, 56: 497-504. DOI
Santificetur, C.; Conversani, V.R.M.; Brenha-Nunes, M.R.; Giaretta, M.B.; Siliprandi, C.C. \& Rossi-Wongtschowski, C.L.D.B. 2017. Atlas of marine bony fish otoliths (sagittae) of Southeastern-Southern Brazil. Part V: Perciformes (Sparidae, Sciaenidae, Polynemidae, Mullidae, Kyphosidae, Chaetodontidae, Mugilidae, Scaridae, Percophidae, Pinguipedidae, Blenniidae, Gobiidae, Ephippidae, Sphyraenidae, Gempylidae, Trichiuridae, Scombridae, Ariommatidae, Stromateidae and (aproidae). Brazilian Journal of Oceanography, 65(2): 201-257. D0I

Santos, R.S.; Azevedo, M.C.C.; Albuquerque, C.Q. \& Araújo, F.G. 2017. Different sagitta otolith morphotypes for the whitemouth croaker Micropogonias furnieri in the Southwestern Atlantic coast. Fisheries Research, 195: 222-229. D0I

Siliprandi, C.C.; Rossi-Wongtschowski, C.L.D.B.; Brenha-Nunes, M.R.; Gonsales, S.A.; Santificetur, C. \& Vaz-dos-Santos, A.M. 2014. Atlas of marine bony fish otoliths (sagittae) of southeastern - southern Brazil. Part II: Perciformes (Carangidae, Sciaenidae, Scombridae and Serranidae). Brazilian Journal of Oceanography, 62: 28-101. DOI

da Silva, V.E.L.; Vieira, D.S.; Teixeira, E.C.; Ferreira, A.C.L.; Assis, I.O.; Rangely, J. \& Fabré, N.N. 2019. Maturity, fecundity and reproductive cycle of Conodon nobilis (Actinopterygii: Perciformes: Haemulidae) in tropical waters of the Atlantic Ocean. Acta Ichthyologica et Piscatoria, 49(3): 235-242. D0l

Soeth, M.; Fávaro, L.F.; Spach, H.L.; Daros, F.A.; Woltrich, A.E. \& Correia, A.T. 2018. Age, growth, and reproductive biology of the Atlantic spadefish Chaetodipterus faber in southern Brazil. Ichthyological Research, 211: 81-90. DOI

Tavares, M.T.M. \& Di Beneditto, A.P.M. 2017. Feeding habits and behaviour of Bagre bagre and Genidens barbus, two ariid catfishes (Pisces: Siluriformes) from southeastern Brazil. Journal of Threatened Taxa, 9(10): 10771-10775. DOI

Taylor, M.D.; Fowler, A.M. \& Suthers, I.M. 2020. Insights into fish auditory structure-function relationships from morphological and behavioural ontogeny in a maturing sciaenid. Marine Biology, 167: 1-11. DOI

The R Project for Statistical Computing (R Core Team). 2020. R: A language and environment for statistical computing. R Foundation for Statistical Computing, Vienna, Austria. https://www.r-project.org.

Torres, G.J.; Lombarte, A. \& Morales-Nin, B. 2000. Variability of the sulcus acusticus in the sagittal otolith of the genus Merluccius (Merlucciidae). Fisheries Research, 46: 5-13. D0I

Tuset, V.M.; Lombarte, A. \& Assis, C.A. 2008. Otolith Atlas for the Western Mediterranean, North and Central Eastern Atlantic. Scientia Marina, 72: 7-198. DOI

Tuset, V.M.; Lozano, I.J.; Gonzalez, J.A.; Pertusa, J.F. \& Garcia-Diaz, M.M. 2003. Shape Indices to Identify Regional Differences in Otolith Morphology of Comber, Serranus Cabrilla (L., 1758). Journal Applied Ichthyology, 19: 88-93. DOI

Volpedo, A. \& Echeverría, D.D. 2003. Ecomorphological Patterns of the Sagitta in Fish on the Continental Shelf off Argentine. Fisheries Research, 60: 551-560. D0I

Volpedo, A.V. \& Vaz-dos-Santos, A.M. 2015. Métodos de estudios con otolitos: principios y aplicaciones. INPA CONICET UBA, Ciudad Autónoma de Buenos Aires. 